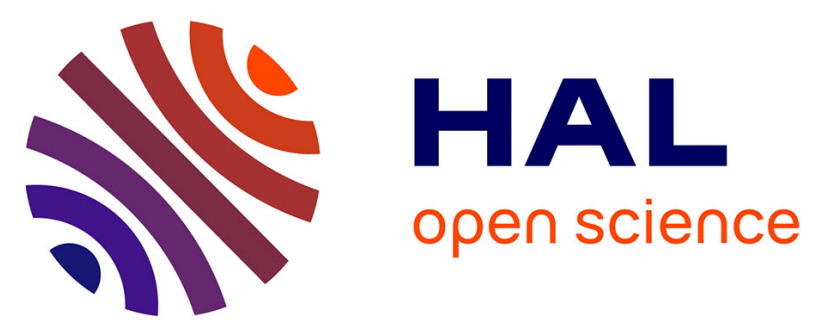

\title{
Intracavernous Injections in Spinal Cord Injured Men With Erectile Dysfunction, a Systematic Review and Meta-Analysis
}

Lucie Chochina, Florian Naudet, Clément Chéhensse, Andréa Manunta, Mireille Damphousse, Isabelle Bonan, François Giuliano

\section{To cite this version:}

Lucie Chochina, Florian Naudet, Clément Chéhensse, Andréa Manunta, Mireille Damphousse, et al.. Intracavernous Injections in Spinal Cord Injured Men With Erectile Dysfunction, a Systematic Review and Meta-Analysis. Sexual Medicine Reviews, 2016, 4 (3), pp.257-269. 10.1016/j.sxmr.2016.02.005 . hal-01295641

\section{HAL Id: hal-01295641 \\ https://hal-univ-rennes1.archives-ouvertes.fr/hal-01295641}

Submitted on 13 Jun 2016

HAL is a multi-disciplinary open access archive for the deposit and dissemination of scientific research documents, whether they are published or not. The documents may come from teaching and research institutions in France or abroad, or from public or private research centers.
L'archive ouverte pluridisciplinaire HAL, est destinée au dépôt et à la diffusion de documents scientifiques de niveau recherche, publiés ou non, émanant des établissements d'enseignement et de recherche français ou étrangers, des laboratoires publics ou privés. 


\title{
Intracavernous injections in spinal cord injured men with erectile dysfunction, a systematic review and meta-analysis
}

Lucie Chochina (1), Florian Naudet (2), Clément Chéhensse (1), Andrea Manunta (3), Mireille Damphousse (1), Isabelle Bonan (1), François Giuliano(4).

1) PRM department of University Hospital of Rennes, FR

2) Pharmacology department of University Hospital of Rennes, FR

3) Urology department of University Hospital of Rennes, FR

4) R. Poincaré hospital - AP-HP, Garches, Inserm U1179, Versailles-Saint Quentin en Yvelines university, Montigny-le-Bretonneux, FR

\begin{abstract}
Objective : To review the efficacy of intracavernous injections (ICI) in spinal cord injured (SCI) men and to identify prognostic factors affecting the efficacy of ICI in this population.

Methods : Systematic review of the literature using Pubmed/Medline, Embase, Ebsco, Web of science and the Cochrane library databases. The literature search was restricted to articles published in English, French and Spanish language up to november 2014 using the key words: alprostadil, papaverine, moxisylyte, alpha-blocking agent, phentolamine, intracavernous injection, spinal cord injuries, paraplegia, quadriplegia, erectile dysfunction. Studies involving SCI patients with erectile dysfunction treated with ICI of alprostadil, papaverine, alpha blocking agents, including retrospective and prospective cohorts, population studies and randomized controlled trials, were included.
\end{abstract}

Results : Out of 283 studies identified, 23 were included involving 713 SCI patients. ICIs resulted in successful erections in $88 \%(\mathrm{n}=713 ; 95 \%$-CI $83 \%$; 92\%) of patients. Erections were obtained respectively in $93 \%$ of patients $(n=101 ; 95 \%$ CI 83\%; 99\%) with the combination of papaverine and phentolamine, in $91 \%(\mathrm{n}=274 ; 95 \%$-CI $78 \%-97 \%)$ with papaverine alone and in $80 \%(\mathrm{n}=$ 119; 95\%-CI 64\%; 90\%) with alprostadil. Type of injected drug, doses, level of injury whether complete or not, extent of the injury, age, time since injury, persistence of erections or not were evaluated but statistical analysis could not identify specific factors predictive of a response to ICI.

Conclusion: ICIs are an effective treatment of erectile dysfunction in SCI men. No predictive factor for efficacy could be identified. Studies comparing the response to ICI in upper and lower motor neuron lesions could improve our understanding of ICI failure.

Systematic review registration - PROSPERO 2014:CRD42014009288.

Key words : paraplegia, quadriplegia, erectile dysfunction, alprostadil, papaverine. 


\section{Introduction}

Despite improvements in the care of patients after SCI, permanent impairment of locomotion, sensation, and autonomic function remain a major hurdle. Sexual and reproductive functions are of primary importance. Once the acute post-injury stage is over, recovering sexual function is the first priority for paraplegics and the second for quadriplegics (1).

Erectile dysfunction (ED), defined as the inability to attain and maintain penile erection sufficient for satisfactory sexual performance (2), is common in SCI patients. In this pathologic context, ED of neurogenic origin depends on the level and the extent of the lesion (3). Reflexive erections triggered by peripheral stimulation, especially when applied to the penis or the perigenital area are present in patients with intact sacral conus medullaris and independent of supraspinal connections. Psychogenic erection triggered by stimuli processed by the brain (visual, auditory, fantasy) are observed in patients with preserved and supra-spinally connected sacral parasympathetic centres located in S2-S4 spinal segments or, in case of injured or disconnected sacral segments, preserved T12-L2 spinal segments $(4,5)$. Overall the exact impairment of erectile function depends on the type of SCI, both in terms of the completeness of the injury and its location within the spinal cord (6). Although most men with SCI can have some type of erection (i.e., psychogenic or reflexive), erectile responses are often not sufficiently predictable, rigid or long-lasting enough for satisfactory sexual intercourse (7-9). Oral phosphodiesterase type 5 inhibitors (PDE5i) are first line treatment option for patients with ED, whatever the aetiology (10). Based on multinational randomized placebo-controlled clinical trials in SCI patients (11-14), in the summary of product characteristics indication section, ED in SCI is actually mentioned for the following PDE5is: sildenafil, vardenafil and tadalafil. SCI patients not responding to PDEi may be proposed intracavernous injections (ICI) (2) or vacuum device. The first in class PDE5 inhibitor, sildenafil, has been launched in 1998, while the first reports about the proerectile effect of intracavernous delivery of papaverine or phentolamine have been provided respectively in 1982 and 1983 (15,16). For ICI commonly used single agents include prostaglandin E1 (PGE1) also named alprostadil, papaverine, and moxisylyte, an alpha adrenoreceptor blocking agent (no longer available). PGE1, papaverine, vasoactive intestinal polypeptide (VIP), phentolamine, phenoxybenzamine, both adrenoreceptor blocking agents or chlorpromazine, have also been combined to treat ED (16-18). The most frequently used combinations include papaverine, phenoxybenzamine (bimix) and PGE1 (trimix). Men or their partners (especially for quadriplegics) must be taught how to inject the penis during the dose titration in the physician's office. First, the material is presented: the pre-filled syringes or the drug vials with the syringes including 28- to 30-gauge needles, and alcohol swabs. Second, patients are instructed to draw up the drugs aseptically in case of not pre-filled syringes. Third, patients are taught how to inject laterally into the left or right corpus cavernosum at a 90-degree angle to the penis, avoiding the urethra and the dorsal penile nerve and the veins. After the injection, it is required to apply a pressure to the injection site for two minutes. Erection usually occurs in a few minutes, independent of sexual stimulation. Pharmacologically induced erection by ICIs are thus different from facilitated erections by PDE5i with a mandatory sexual stimulation. After an adequate training by an experienced physician, home self-injection therapy program can be initiated. The titration of the dose required to achieve a satisfactory erection remains unpredictable 
in SCI patients and sometimes ICIs fail. Then, vacuum or in rare case of failure, penile implants, as third line treatments, can be proposed. Predictive factors for ICI's success in SCI patients have not been evaluated so far.

The objectives of this systematic review and meta-analysis were to assess i) the efficacy of ICI, and to attempt to determine ii) demographic and iii) predictive factors of ICI's response in terms of spinal cord lesion in SCI patients.

\section{Methods}

This review followed the PRISMA (Preferred Reporting Items for Systematic Reviews and MetaAnalysis) guidelines (19). We developed and followed a standard protocol of meta-analysis recorded on the PROSPERO database (20) with the following registration number: PROSPERO 2014:CRD42014009288.

\section{Eligibility Criteria:}

\section{Type of participants:}

We reviewed studies reporting data about SCI men with erectile dysfunction (ED).

Type of intervention:

Studies were eligible if they involved the use of ICIs, whatever the drug used.

Types of studies:

All prospective and retrospective designs assessing the response to ICI were eligible for this review: randomized controlled trials (RCT), non randomized cohort studies and cases series could be included. Literature search was restricted to reports in English, French and Spanish language published up to November 2014.

\section{Type of outcome:}

Studies were retained if they reported ICI's response defined as i) Schrameck scale grade $\geq 4 / 5$ (grade 1: no erection, grade 2: slight tumescence, grade 3: full volume without rigidity, grade 4: sufficient for sexual intercourse, grade 5: full erection) (21) and/or ii) rigidity allowing intromission and/or iii) full erection and/or iv) successful intercourse and/or v) satisfactory erection suitable for sexual intercourse.

\section{Search strategy:}

Eligible studies were identified from PubMed/Medline, the Cochrane library, Embase, EBSCO, and Web of science databases. In a first step, an initial search on Medline was carried out in order to refresh optimal search terms. The search terms retained were double-checked before starting the main search within all the above-mentioned databases. A final search was undertaken using the reference lists of articles identified (including previous meta-analysis). The initial MeSH (Medical Subject Headings) terms used were: "alprostadil" OR "papaverine" OR "intracavernous injection" OR "moxisylyte" OR "phentolamine" AND "spinal cord injuries" OR "paraplegia" OR "quadriplegia" AND "erectile dysfunction". 


\section{Studies selection:}

Eligibility assessment was performed independently in a blinded standardized manner by 2 reviewers (CL and CC) and subsequently cross-checked. Disagreements were resolved by consensus or by a third reviewer (NF). A comparison across the studies, checking for author names, treatments, sample sizes and outcomes was performed to avoid duplicates and compilations of data from several reports of the same series.

\section{Assessment of methodological quality:}

Each article was then assessed for methodological quality prior to inclusion in the review using an appropriate standardized critical appraisal instrument: i) the check-list from de Institute of Health Economics (IHE) (22) for the case series and ii) the check-list from STROBE (23) for studies with any other design.

\section{Data collection:}

Two authors (CL and CC) extracted data from the studies included. Disagreements were resolved by consensus or by a third author (NF).

For each included study, information was extracted on: i) characteristics of the study (sample size, year); ii) characteristics of trial participants (age, gender, duration of SCI, characteristics of the injury: whether the lesion was complete or not, level, evaluation of somatic spinal reflex arcs, upper and lower limits when available; iii) type of the intervention: single ICI or titration, injected drug; iv) outcome measure (number of responders); v) side effects (not pre-specified in PROSPERO registration). For each study, aggregated data were extracted and when available (in case series) individual data were extracted. When a valid e-mail address was provided in the publication for the corresponding author, we contacted him in order to collect the individual data.

\section{Data analysis:}

Analysis of overall response rate to ICI was assessed using aggregated data. For all type of studies we performed a meta-analysis of the response rate (giving an estimation of the percentage of responders with a 95\% confidence interval). We used visual inspection of the forest plots, the $\mathrm{I}^{2}$ index and the Q statistic to investigate the possibility of statistical heterogeneity. In the absence of heterogeneity we performed meta-analysis with a fixed-effects model; in case of possible heterogeneity, we performed meta-analysis with a random effect model.

Individual data were used to explore predictive factors of ICI's response through a regression model (i.e. a meta-regression). The dependent variable was erectile response to ICI and the following explanatory variables were explored: injected drug, doses, level of injury, whether the spinal lesion was complete or not, extent of the SCI, age, time since SCI, persistence of erections or not. These meta-regressions were performed with «study» and «subject» factors specified as random effect (mixed model). In certain studies a subject could have different treatments. We had initially planned a meta-regression analysis on aggregated data to explore predictive factors of ICI's response, but the quality of the information, the possibility of major ecological biases (particularly when averages of patient characteristics in each trial were used as covariates in the regression) (24) could not allow this analysis to be carried out. 


\section{Subgroup analysis:}

Meta-analysis were performed to estimate the overall erection rates and for each different treatment.

\section{Risk of bias across studies}

Because of an important heterogeneity, publication bias could not be investigated either graphically (using funnel plots) or by testing (using the rank correlation test) (22). Analyses were performed using R (25) with libraries meta (26) and rmeta (27) and lmer (28).

\section{Results}

\section{Identification:}

After adjusting for duplicates the searches provided 166 publications. 127 of these publications were discarded based on title and abstract because they did not meet the selection criteria. After review of the full text of the 39 remaining articles, 16 additional publications were discarded. 23 articles were finally included for the overall analysis (Figure 1). Only 4 articles provided individual data (29-32). All studies were conducted from October 1982 to November 2014.

\section{Studies characteristics and risk of bias within studies:}

Only one out of the 23 included studies was a double blind randomized controlled clinical trial with a cross over design (33). Data are summarized in Table 1. All studies were single centre.

The overall analysis involved 713 SCI men. The study sample sizes ranged from 6 to 101 SCI patients with a median of 28 patients.

The quality assessment performed is summarized in Table 1. The scoring ranges from zero to 18 (IHE check-list) or 22 (STROBE check-list), with higher scores indicating higher quality. Median quality of included studies was i) $9 / 18$ [with a range of $5 / 18$ to $12 / 18$ ] for the 16 case-series evaluated with the IHE check-list and ii) 13/22 [with a range of 6.5/22 to 16/22] for the 7 studies evaluated with the STROBE check-list.

Protocols of ICI were different but in the majority of the studies titration was performed until full erection was obtained (Table 1). The drug most frequently injected was papaverine (274 men), followed by PGE1 (119 men) and the combination papaverine-phentolamine (bimix) (100 men). Moxisylyte was used in 3 different studies conducted in the same centre $(29,33,34)$. Trimix was tested in only one study (30 men) 35). The maximum injected doses were: papaverine: $90 \mathrm{mg}$, PGE1: $40 \mu \mathrm{g}$, papaverine + phentolamine: $80 \mathrm{mg}+10 \mathrm{mg}$, moxisylyte: $30 \mathrm{mg}$, and trimix: papaverine $30 \mathrm{mg}+$ phentolamine $0,05 \mathrm{mg}+5 \mu \mathrm{g}$ ( Table 2).

The quality of the erection induced by ICI was assessed by the Schrameck scale in 4 studies (17\%), described as "full erection" in 6 studies (26\%), as "satisfactory erection" in 2 studies (9\%) and as "erection with rigidity allowing intromission or intercourse" in 11 studies (48\%).

Demographic and clinical characteristics of the participants included in the different studies are summarized in Table 3.

\section{Overall response rate to $\mathrm{ICI}$ :}


All drugs taken together, ICIs resulted in successful erection in $88 \%(\mathrm{n}=713$; 95\%-CI 83\%; 92\%) of SCI patients. Results are outlined in Figure 2.

\section{Subgroup meta-analysis:}

Meta-analyses were performed to estimate the overall response rate to ICI and the rate of success for each different drug. Results of meta-analysis per drug are presented in Figure 3 . The number of patients per drug (553) differs from the number of patients in the meta-analysis of overall efficacy (713)because : i) 173 men were excluded from the meta-analysis per drug because in a few studies there was no information available regarding which drug was injected (36 4037, 39-42) and ii) 13 patients treated with two different drugs have been double-counted in the meta-analysis of the efficacy per drug $(30,43)$. Satisfactory erection permitting sexual intercourse was obtained with papaverine (mean dosing $17 \mathrm{mg})$ in $91 \%(\mathrm{n}=274 ; 95 \%$-CI 64\%;97\%) (30,32,35,43-47), with PGE1 (mean dosing $12 \mu \mathrm{g})$ in $80 \%(\mathrm{n}=119$; 95\%-CI 64\%;90\%) $(30,31,36,48,49)$, with bimix (mean dosing $15 \mathrm{mg}$ papaverine and $0,4 \mathrm{mg}$ phentolamine in 93\% ( $\mathrm{n}=100 ; 95 \%$-CI 83,\%; 99\%) $(43,44,50,51)$, with moxisylyte (mean dosing $22 \mathrm{mg})$ in $83 \%(\mathrm{n}=30 ; 95 \%$-CI $77 \%$; 98\%) $(29,33,34)$, and with trimix (mean dosing $4 \mathrm{mg}$ papaverine, $0,02 \mathrm{mg}$ phentolamine, 1,5 $\mu \mathrm{g}$ PGE1) in $100 \%(\mathrm{n}=30,95 \%$-CI 88\%; 100\%) (38). Random effects model was used in these analyses (except for moxisylyte and trimix) due to heterogeneity between the different studies (i.e. $\mathrm{I}^{2}>25 \%$ and/or a significant Q statistic).

\section{Individual data meta-analysis:}

Information about individual patients was only provided in 4 studies $(29,31,32,45)$. These studies were included in the individual data meta-analysis (for one of these studies, only patient's age was available). Overall response rate in these 4 studies was $92 \%$ [95\%-CI 68\%-98\%].

No results were statistically relevant for $i)$ the effect of age $(p=0.49)$, ii) whether the lesion was complete or not $(p=0.26)$, iii) the dose of papaverine $(p=0.82)$ or of PGE1 $(p=0.98)$ and iv) the level of the lesion according to the following classification: above T10, between T10 and L2, below L2 (p-value resulting of the mixed model>0.05).

\section{Side effects:}

Tolerability of injected drugs was acceptable with an overall complication rate of $13.3 \%(\mathrm{n}=685$, CI-95\% 11\%;16\%), respectively $2 \%$ for PGE1 $(n=119$, CI-95\% $1 \% ; 6 \%), 0 \%$ for moxisylyte $(n=30)$ and $13 \%$ for papaverine $(n=262$, CI-95\% 9\%;17\%). The combination of papaverine with phentolamine was responsible for higher complication rate of $30 \%(\mathrm{n}=69$, CI-95\% $21 \% ; 42 \%)$. The main side effects were ecchymosis $5 \%(\mathrm{n}=685$, CI-95\% 3.5\%; 7\%), prolonged erection $(\geq 3$ hours) $4 \%(n=685$, CI 95\% 3\%; 6\%), priapism ( $\geq$ 4hours) $3 \%(n=685 \%$, CI-95\% 2\%;4\%), 5 cases of fibrosis $(n=685$, CI-95\% $0.5 \%-2 \%), 5$ cases of pain $(n=685$, CI-95\% $0.5 \%-2 \%)$, 3 cases of urethrorrhagia $(n=685$, CI-95\% $0.1-1.5 \%)$. 


\section{Discussion}

\section{Summary of evidence}

Recovery of penile erection in SCI patients allowing sexual intercourse with vaginal penetration did represent an issue. Prior to the launch of sildenafil in 1998, ICI was the only pharmacological treatment available for ED whatever the aetiology of the condition. Overall response rate to ICIs for ED in SCI patients was $88 \%$. In 2006, DeForge et al (52) conducted a meta-analysis including 11 publications about ICI in SCI patients and reported similar results. In this former study, the search strategy was different due to different objectives which were i) morbidity of ICI compared with oral therapy and ii) PGE1 ICI compared with other injected drugs. In the present review, 12 additional trials have been added in the analysis representing 395 added patients.

Since sildenafil approval, ICI became second line treatment for ED in case of failure of PDE5i or rarely, when PDE5i are contraindicated. According to the summary of product characteristics in the US, the contraindications for alprostadil IC injections are as follows: "Alprostadil should not be used in patients who have conditions that might predispose them to priapism, such as sickle cell anaemia or trait, multiple myeloma, or leukaemia; or in patients with anatomical deformation of the penis, such as angulation, cavernosal fibrosis, or Peyronie's disease. Patients with penile implants should not be treated with alprostadil. Alprostadil should not be used in men for whom sexual activity is inadvisable or contraindicated". These contraindications are all applicable to SCI patients. These contraindications are the same for other pharmacological substances IC delivered.

With most studies conducted prior to 1998, the vast majority of SCI patients treated with ICI have not been exposed to PDE5i apart in two studies. In a cohort of upper motor neuron injured patients (37), 20 patients received PDE5i after ICI and both treatments resulted in the same IIEF-EF score. In a cohort of conus medullaris injured patients (48), without a cross-over design, 31\% (12/39) patients who received PDE5i obtained an erection grade $\geq 4 / 5$ (Schrameck scale), compared to $82 \%$ (40/49) patients treated with ICI. The response rate of SCI patients to ICI was found comparable between the different drugs or combination of drugs, but a statistical comparison could not be performed due to the retrospective design of most of the studies, and the absence of control groups. The most widely used drug was papaverine, because many studies were conducted prior to the development of PGE1 ICI. Indeed PGE1 has been developed posteriorly to the off label use of papaverine and phentolamine, which have both never been approved by regulatory authorities in the ED indication. PGE1 is currently the preferred compound for ICI because of a claimed lower complication rate, especially as far as priapism is concerned (53). In the included studies, the maximal injected dose of each drug was in most cases above the recommended dose (54). Tolerability for these high doses of injected drugs was acceptable with an overall complication rate of $13 \%$, decreasing to $2 \%$ for PGE1 (mainly prolonged erection).

The heterogeneity in the selected studies regarding the drug used and the outcome measures prevents to draw any conclusion about which drug or dose should be proposed for which patients. No predictive factors of response rate have been found.

\section{Limitations}

Most of the included studies were of low or poor quality. They were mainly case series with only one study based on a crossover randomized design. However the superiority of PGE1, papaverine, papaverine combined with phentolamine and moxisylyte over placebo was previously demonstrated in patients with ED from non-neurological origin $(29,56,57)$. 
A reporting bias at the level of the publication could not be excluded ("negative" studies might have not been published) or at the level of outcome reporting (only favourable outcomes were reported in the published reports). Most studies are retrospective and data could have been incompletely reported or missing. The results could have been different, if the study design would have been prospective. Such a bias could (at least partly) explain the overall high response rate to ICI encountered in this review.

Individual clinical data were not detailed in all studies and consequently could not be pooled in subgroup meta-analysis and individual data meta-analysis.

There was a lack of standardization in the literature in the description of included population. Most series reported that patients were paraplegic or quadriplegic but few authors reported the exact level of injury or the ASIA/Frankel score and fewer mentioned the persistence of a sacral reflex. The level of the injury is insufficient to characterize if the lesion concerns the upper or the lower motor neuron with interruption of the sacral somato-somatic reflex loop $(58,59)$. Information concerning the integrity of the sacral arc, the most important for the proerectile parasympathetic innervation of the erectile tissue, was most often missing (60). 
There was neither study reporting urodynamic investigation nor neurophysiological testing as somato-sensory evoked potentials (SSEP), bulbocavernous reflex latency recording (BCR), or sympathetic skin response (SSR). Urodynamic investigation indirectly assesses the parasympathetic innervation to the pelvis. Detrusor hyperreflexia is constantly associated with preserved reflex erections as opposed to patients with detrusor areflexia. Rydin et al (61) showed that both reflex erection and micturition are dependent on an intact conus medullaris and its reflex loops. BCR evaluates the function of conus medullaris and sacral nerves roots by testing the sacral somatosomatic reflex loop. SSR assesses the sympathetic nervous system. Schmid et al (62) found a positive association between the presence or not of psychogenic erection and perineal SSR. Pudendal SSEP evaluate the afferent somatosensory spinal pathways from the genitals to the brain areas related to sexual function. These complementary specifications may allow to allocate the patients with neurogenic ED to specific sub-groups. Such sub-group analyses could improve our understanding of the exact pathophysiology of ED based on segmental spinal cord lesions and therapeutic efficacy.

Few authors have used a validated erectile grading scale such as Schrameck scale or the EF domain of the IIEF questionnaire (questions 1-5 and question 15 focusing on erection) or the abridged version IIEF-5 available only in the late 90's, whereas the majority have used their own non validated grading system (63-65). In assessing subjectively the response to ICI, the concept of full rigidity has not been clearly defined in the literature and is therefore subject to variation between data retrieved in medical environment and data self-reported by the patient. When objective erection grading scale was missing, we chose to include different erection assessments focusing on a satisfactory erection permitting sexual intercourse because patient's satisfaction is the primary objective of ED treatment. We did not evaluate the duration of pharmacologically-induced erection as this information was missing in most studies; this would have been interesting because SCI patients often complain of unsustained erection.

\section{Perspectives}

\section{Level of SCI and ICI efficacy}

Bearing in mind these limitations, we did not find any evidence for the influence of the level of the SCI on ICI response. We initially thought that a lower motor neuron injury could have a negative impact on ICI response rate or might require higher doses of injected drugs, particularly when the delay between SCI and the first injection was long. Lower motor neuron lesion injury is characterized by Comarr (59) as the absence of bulbocavernous reflex and/or sphincter anal tone, this means, that the lesion concerns either the sacral segments or sacral nerves. It has been reported that lower motor neuron injured patients tend not to respond well to PDE5i (66) which require a sexual stimulation to be effective, but can respond to ICI, which induce erection independent of sexual desire. In a cohort of conus medullaris injured patients, Hadiji et al (48) reported that $82 \%$ of them obtained erection equal or above 4/5 in Schrameck scale with ICI (PGE1 highest dose $40 \mu \mathrm{g}$ or papaverine $20 \mathrm{mg}$ if PGE1 fails). This response rate was close to the overall response rate found in the present meta-analysis. In Schmid series (62), the extent of the lesion, more than its level was 
predictive for the loss of all types of erection. In this study, myelomalacia extending from T8 to S5 involving both the thoraco-lumbar as well as the sacral spinal centres commanding penile erection was associated with loss of all types of erection. All SCI patients with ED responded to ICI-test even if they have no reflexive, nor psychogenic nor nocturnal erection. No studies included in the present review reported the extent of lesion so that we cannot conclude whether the extent of lesion is a determinant for erectile response to ICI. Nevertheless, because ICI exerts a strictly local effect on the mechanisms of penile erection i.e. direct relaxation of smooth muscle cells in the corpora cavernosa and vasodilation of helicine arteries within the erectile tissue, it seems unlikely that the extent of the spinal lesion can dramatically influence the response to ICI.

\section{Severity, time elapsed since injury and response to ICI treatment}

The time elapsed between SCI and the initiation of ICI treatment might have a negative impact on the response rate. In ED patients after radical prostatectomy for localized prostate cancer, it is recommended to start as early as possible post-prostatectomy ICI treatment (67). Postprostatectomy ED is due at least partly to damage to cavernous nerves which convey proerectile parasympathetic innervation to the erectile tissue. This condition is thus somewhat similar to other types of lower motor neuron injuries such as lesions of the cauda equina or conus medullaris. Upper motor neuron lesions are frequently associated with the persistence of reflex erections and nocturnal penile tumescence with improved tissue oxygenation which might reduce the risk of fibrosis of corpora cavernosa (62).

Unfortunately most series included in the present meta-analysis did not report individual data but only the overall mean duration since SCI so that the impact of this variable on ICI response could not be analysed.

The severity of the injury might also influence ICI efficacy. Incomplete lesions could be a positive predictive factor of ICI efficacy: Conejero et al (36) carried out a subgroup-analysis comparing complete to incomplete injuries but without a proper statistical analysis and no adjustment for potential confounders such as the level of injury or patient's age. Most series $(37,42,47)$ did not report a better response to ICI in incomplete SCI, but the studies were not specifically designed to evaluate this variable.

Due to all these limitations we could not confirm that a lower motor neuron lesion and/or a prolonged delay between injury and ED treatment impact ICI response rate. Therefore we do not have a rationale to propose an early treatment with ICI after lower motor neuron lesion in case of PDE5i failure in SCI patients.

\section{Age and ICI efficacy}

Ageing is a well known risk factor for ED in the general population (2). The aged-related endothelial dysfunction can be the most significant factor. Chung et al (68) studied the age-related penile arterial flow change during pharmacologically-induced erection by ICI. Maximum peak systolic velocity was reached later following ICI in patients aged 50 and above, but the resistance index did not differ compared to younger patients. Although ageing impacts peak systolic velocity, 
all patients responded to ICI (10 $\mu \mathrm{g}$ of PGE1). In the present meta-analysis, we did not find any relationship between age and response to ICI in SCI patients.

More than age itself, pathological ageing seems to have an impact on ED. Cardiovascular risk factors or conditions including arterial hypertension, dyslipidemia and diabetes mellitus are more frequent in older patients (59) and may cause the build up of atherosclerotic plaques in the pudendal and penile arteries, impairing the cavernosal inflow necessary to normal erectile function (69). Endothelial dysfunction is another well identified pathophysiological mechanism for ED in patients with cardiovascular risk factors and/or conditions. In a series by Zaslau et al (70) 8 out of the 9 SCI patients who did not respond to ICI had either diabetes mellitus or hypertension or both. The impact of comorbidity(ies) and ageing on the response to ICI could not be evaluated in this meta-analysis because of lack of data in the included series.

\section{Recommendations}

Based on the present review we can provide with the following recommendations:

The efficacy of ICI in SCI patients is $88 \%$ (level of evidence: 4 , recommendation: C). In terms of tolerability in SCI patients, PGE1 appears better when compared to papaverine or phentolamine (level of evidence: 4, grade of recommendation: $\mathrm{C}$ ).

\section{Conclusion}

ICI undoubtedly represents an effective treatment for ED in SCI patients with a high response rate near to $90 \%$ in this population. This systematic review could not identify any specific predictive factor of a successful outcome because of the lack of individual data reporting, and the absence of a standardization in the results obtained in the published series.

Cohort studies will be required to evaluate the individual impact of different factors such as the level of injury, the extent of the lesion and whether its completeness, the time elapsed since SCI or the patient's age could impact ICI's response rate. A separate evaluation of response in upper and lower motor neuron lesions could also help to better understand the few failures of ICI.

A better understanding of the impact of individual factors on ICI response will help to further improve the management of ED in SCI patients non responders to PDE5i. 


\section{References}

1. Anderson KD. Targeting recovery: priorities of the spinal cord-injured population. J Neurotrauma 2004;21:1371-83.

2. Montorsi F, Adaikan G, Becher E, Giuliano F, Khoury S, Lue TF, Sharlip Ira, Althof SE, Andersson KE, Brock G, Broderick G, Burnett A, Buvat J, Dean J, Donatucci C, Eardley I, Fugl-Meyer KS, Goldstein I, Hackett G, Hatzichristou D, Hellstrom W . Summary of the recommendations on sexual dysfunctions in men. J Sex Med 2010;7:3572-88.

3. Schmid DM, Curt A, Hauri D, Schurch B. Clinical value of combined electrophysiological and urodynamic recordings to assess sexual disorders in spinal cord injured men. Neurourol Urodyn 2003;22:314-21.

4. Bors E, Comarr AE. Neurological disturbances of sexual function with special reference to 529 patients with spinal cord injury. Urol Surv 1960;10:191-222.

5. Comarr AE. Sexual function among patients with spinal cord injury. 1970;134-68.

6. Courtois FJ, Charvier KF, Leriche A, Raymond DP, Eyssette M. Clinical approach to erectile dysfunction in spinal cord injured men. A review of clinical and experimental data. Paraplegia 1995;33:628-35.

7. Stone A. The sexual needs of the injured spinal cord patient. Probl Urol 1987;1:529-36.

8. Barbonetti A, Cavallo F, Felzani G, Francavilla S, Francavilla F. Erectile Dysfunction is the Main Determinant of Psychological Distress in Men with Spinal Cord Injury. J Sex Med 2012;9:830-6.

9. Biering-Sörensen I, Hansen R, Biering-Sorensen F. Sexual function in a traumatic spinal cord injured population 10 -45 years after injury. J Rehabil Med. 2012;44:926-31.

10. Hatzimouratidis K, Amar E, Eardley I, Giuliano F, Hatzichristou D, Montorsi F, Vardi Yoram, Wespes E. Guidelines on Male Sexual Dysfunction: Erectile Dysfunction and Premature Ejaculation. Eur Urol 2010;57:804-14.

11. Rizio N, Tran C, Sorenson M. Efficacy and satisfaction rates of oral PDE5is in the treatment of erectile dysfunction secondary to spinal cord injury: a review of literature. J Spinal Cord Med 2012;35:219-28.

12. Giuliano F, Hultling C, El Masry WS, Smith MD, Osterloh IH, Orr M, Maytom M. Randomized trial of sildenafil for the treatment of erectile dysfunction in spinal cord injury. Sildenafil Study Group. Ann Neurol 1999;46:15-21.

13. Giuliano F, Rubio-Aurioles E, Kennelly M, Montorsi F, Kim ED, Finkbeiner AE, Pommerville PJ, Colopy MW, Wilkins HJ, Wachs BH . Efficacy and safety of vardenafil in men with erectile dysfunction caused by spinal cord injury. Neurology 2006;66:210-6.

14. Giuliano F, Sanchez-Ramos A, Löchner-Ernst D, Del Popolo G, Cruz N, Leriche A, Lombardi G, Reichert S, Dahl P, Elio-Mboussa A, Casariego J. Efficacy and safety of tadalafil in men with erectile dysfunction following spinal cord injury. Arch Neurol 2007;64:1584-92.

15. Virag R. Intracavernous injection of papaverine for erectile failure. Lancet 1982;2:938. 
16. Brindley GS. Cavernosal alpha-blockade: a new technique for investigating and treating erectile impotence. Br J Psychiatry J Ment Sci 1983;143:332-7.

17. Eardley I, Donatucci C, Corbin J, El-Meliegy A, Hatzimouratidis K, McVary K, Munarriz R, Won Lee S. Pharmacotherapy for erectile dysfunction. J Sex Med 2010;7:524-40.

18. Shamloul R, El-Dakhly M, Ghanem H, Gadallah A, Mokhtar H. Intracavernous chlorpromazine versus phentolamine: a double-blind clinical comparative study. J Sex Med 2004;1:310-3.

19. Moher D, Liberati A, Tetzlaff J, Altman DG, PRISMA Group. Preferred reporting items for systematic reviews and meta-analyses: the PRISMA statement. J Clin Epidemiol 2009;62:1006-12.

20. Chien PFW, Khan KS, Siassakos D. Registration of systematic reviews: PROSPERO. BJOG Int J Obstet Gynaecol 2012;119:903-5.

21. Schramek P, Dorninger R, Waldhauser M, Konecny P, Porpaczy P. Prostaglandin E1 in erectile dysfunction. Efficiency and incidence of priapism. Br J Urol 1990;65:68-71.

22. Institute of Health Economics A CANADA. Development of quality appraisal tool for case series studies using a modified Delphi technique. Available on: http://ihe.ca/

23. Sterne JAC, Sutton AJ, Ioannidis JPA, Terrin N, Jones DR, Lau J, Carpenter J, Rücker G, Harbord RM, Schmid CH, Tetzlaff J, Deeks JJ, Peters J, Macaskill P, Schwarzer G, Duval S, Altman DG, Moher D, Higgins JPT. Recommendations for examining and interpreting funnel plot asymmetry in meta-analyses of randomised controlled trials. BMJ 2011;343:d4002.

24. Thompson SG, Higgins JPT. How should meta-regression analyses be undertaken and interpreted? Stat Med 2002;21:1559-73.

25. Team DC. R Development Core Team, R: A language and environment for statistical computing. R Foundation for Statistical Computing, 2010, Vienna, Austria. ISBN 3-900051-070 .

26. Schwarzer G. meta: meta-analysis with R. R package version 1.1-8. 2010, URL http://CRAN.Rproject.org/ package $=$ meta.

27. Lumley T. «rmeta: Meta-Analysis. » R package version 2.16. 2009, URL http://CRAN. Rproject.org/package $=$ rmeta.

28. Bates D, Machler M, Bolker B, Walker S. Fitting Linear Mixed-Effects Models using lme4. Journal of Statistical Software, 2015, 67: 1-48. URL http://arxiv.org/abs/1406.5823

29. Costa P, Bressolle F, Sarrazin B, Mosser J, Navratil H, Galtier M. Moxisylyte plasma kinetics in humans after intracavernous administration. Biopharm Drug Dispos 1992;13:671-9.

30. Schurch B, Kuhn W. Erectile dysfunction of male spinal cord injury patients. Schweiz Rundsch Für Med Prax Rev Suisse Médecine Prax 1990;79:1085-8.

31. Tang SF, Chu NK, Wong MK. Intracavernous injection of prostaglandin E1 in spinal cord injured patients with erectile dysfunction. A preliminary report. Paraplegia 1995;33:731-3.

32. Yarkony GM, Chen D, Palmer J, Roth EJ, Rayner S, Lovell L. Management of impotence due to spinal cord injury using low dose papaverine. Spinal Cord 1995;33:77-9. 
33. Costa P, Sarrazin B, Bressolle F, Colson MH, Bondil P, Saudubray F. Efficiency and side effects of intracavernous injections of moxisylyte in impotent patients: a dose-finding study versus placebo. J Urol 1993;149:301-5.

34. Costa P, Sarrazin B, Bressolle F, Mottet N, Louis JF, Saudubray F,Navatril H. Is the volume injected a parameter likely to influence the erectile response observed after intracavernous administration of an alpha-blocking agent? Eur Urol 1993;24:43-7.

35. chao

Beretta G, Zanollo A, Fanciullacci F, Catanzaro F. Intracavernous injection of papaverine in paraplegic males. Acta Eur Fertil 1986;17:283-4.

36. J, Muñoz Villellas A, Sarrias Lorenz F, Ramírez Garceran L. Prostaglandin treatment in neurological patients with erectile dysfunction. Arch Esp Urol 2002;55:63-8.

37. Moemen MN, Fahmy I, AbdelAal M, Kamel I, Mansour M, Arafa MM. Erectile dysfunction in spinal cord-injured men: different treatment options. Int J Impot Res 2008;20(2):181-7.

38. Chao R, Clowers DE. Experience with intracavernosal tri-mixture for the management of neurogenic erectile dysfunction. Arch Phys Med Rehabil 1994;75:276-8.

39. Earle CM, Keogh EJ, Ker JK, Cherry DJ, Tulloch AGS, Lord DJ. The role of intracavernosal vasoactive agents to overcome impotence due to spinal cord injury. Spinal Cord. 1992;30:273-6.

40. Zaslau S, Nicolis C, Galea G, Britanico J, Vapnek JM. A simplified pharmacologic erection program for patients with spinal cord injury. J Spinal Cord Med. 1999;22:303-7.

41. Bodner DR, Leffler B, Frost F. The role of intracavernous injection of vasoactive medications for the restoration of erection in spinal cord injured males: a three year follow up. Spinal Cord. 1992;30:118-20.

42. Lebib Ben Achour S, Laffont I, Boyer F, Boiteau F, Dizien O. Intracavernous injections in the treatment of erectile dysfunction in spinal cord injured patients: experience with 36 patients. Ann Réadaptation Méd Phys 2001;35-40.

43. Sidi AA, Cameron JS, Dykstra DD, Reinberg Y, Lange PH. Vasoactive intracavernous pharmacotherapy for the treatment of erectile impotence in men with spinal cord injury. $\mathrm{J}$ Urol 1987;138:539-42. 
44. Bodner DR, Lindan R, Leffler E, Kursh ED, Resnick MI. The application of intracavernous injection of vasoactive medications for erection in men with spinal cord injury. $J$ Urol 1987;138:310-1.

45. Kapoor VK, Chahal AS, Jyoti SP, Mundkur YJ, Kotwal SV, Mehta VK. Intracavernous papaverine for impotence in spinal cord injured patients. Paraplegia 1993;31:675-7.

46. Renganathan R, Suranjan B, Kurien T. Comparison of transdermal nitroglycerin and intracavernous injection of papaverine in the treatment of erectile dysfunction in patients with spinal cord lesions. Spinal Cord 1997;35:99-103.

47. Yildiz N, Gokkaya NKO, Koseoglu F, Gokkaya S, Comert D. Efficacies of Papaverine and Sildenafil in the Treatment of Erectile Dysfunction in Early-Stage Paraplegic Men. Int J Rehabil Res 2011;34:44-52.

48. Hadiji N, Benbouzid R, Previnaire JG, Leblond C, Mieusset R, Enjalbert M, Soler JM. Evaluation of treatment of erectile and ejaculatory dysfunction in a series of 90 spinal cord injured. Progres en Urologie 2013;23:1489-93.

49. Hirsch IH, Smith RL, Chancellor MB, Bagley DH, Carsello J, Staas WE Jr. Use of intracavernous injection of prostaglandin E1 for neuropathic erectile dysfunction. Paraplegia 1994;32:661-4.

50. Wyndaele JJ, Meyer JM de, de Sy WA, Claessens H. Intracavernous injection of vasoactive drugs, an alternative for treating impotence in spinal cord injury patients. Spinal Cord 1986;24:271-5.

51. Lloyd LK, Richards JS. Intracavernous pharmacotherapy for management of erectile dysfunction in spinal cord injury. Paraplegia 1989;27:457-64.

52. Deforge D, Blackmer J, Garritty C, Yazdi F, Cronin V, Barrowman N, Fang M, Mamaladze V, Zhang L, Sampson M, Moher D. Male erectile dysfunction following spinal cord injury: a systematic review. Spinal Cord 2006;44:465-73.

53. Bechara A, Casabe A, Cheliz G, Romano S, Rey H, Fredotovich N. Comparative Study of Papaverine Plus Phentolamine Versus Prostaglandin E1 in Erectile Dysfunction. J Urol 1997;157:2132-4.

54. Gutierrez P, Hernandez P, Mas M. Combining programmed intracavernous PGE1 injections and sildenafil on demand to salvage sildenafil nonresponders. Int J Impot Res. 2005;17(4):354-8.

55. Godschalk MF, Chen J, Katz PG, Mulligan T. Treatment of erectile failure with prostaglandin E1: a double-blind, placebo-controlled, dose-response study. J Urol 1994;151:1530-2. 52.

Gasser TC, Roach RM, Larsen EH, Madsen PO, Bruskewitz RC. Intracavernous selfinjection with phentolamine and papaverine for the treatment of impotence. $J$ Urol 1987;137:678-80.

56. Szasz G, Stevenson RW, Lee L, Sanders HD. Induction of penile erection by intracavernosal injection: a double-blind comparison of phenoxybenzamine versus papaverine-phentolamine versus saline. Arch Sex Behav 1987;16:371-8.

57. Chapelle PA, Durand J, Lacert P. Penile erection following complete spinal cord injury in man. Br J Urol 1980;52:216-9. 
58. Comarr AE. Sexual concepts in traumatic cord and cauda equina lesions. J Urol 1971;106:375-8.

59. Doherty JG, Burns AS, O'Ferrall DM, Ditunno JF. Prevalence of upper motor neuron vs lower motor neuron lesions in complete lower thoracic and lumbar spinal cord injuries. J Spinal Cord Med 2002;25:289-92.

60. Rydin E, Lundberg PO, Brattberg A. Cystometry and mictometry as tools in diagnosing neurogenic impotence. Acta Neurol Scand 1981;63:181-8.

61. Schmid DM, Hauri D, Schurch B. Nocturnal penile tumescence and rigidity (NPTR) findings in spinal cord injured men with erectile dysfunction. Int J Impot Res 2004;16:433-40.

62. Rosen RC, Riley A, Wagner G, Osterloh IH, Kirkpatrick J, Mishra A. The international index of erectile function (IIEF): a multidimensional scale for assessment of erectile dysfunction. Urology 1997;49:822-30.

63. Rosen RC, Cappelleri JC, Smith MD, Lipsky J, Peña BM. Development and evaluation of an abridged, 5-item version of the International Index of Erectile Function (IIEF-5) as a diagnostic tool for erectile dysfunction. Int J Impot Res 1999;11:319-26.

64. Giuliano F. Les questionnaires recommandés en médecine sexuelle. Prog En Urol 2013;23:811-21.

65. Schmid DM, Schurch B, Hauri D. Sildenafil in the treatment of sexual dysfunction in spinal cord-injured male patients. Eur Urol 2000;38:184-93.

66. Salonia A, Burnett AL, Graefen M, Hatzimouratidis K, Montorsi F, Mulhall JP, Stief C. Prevention and Management of Postprostatectomy Sexual Dysfunctions Part 2: Recovery and Preservation of Erectile Function, Sexual Desire, and Orgasmic Function. Eur Urol 2012;62:273-86. 
67. Chung WS, Park YY, Kwon SW. The Impact of Aging on Penile Hemodynamics in Normal Responders to Pharmacological Injection: A Doppler Sonographic Study. J Urol 1997;157:2129-31.

68. Solomon H, Man JW, Jackson G. Erectile dysfunction and the cardiovascular patient: endothelial dysfunction is the common denominator. Heart Br Card Soc 2003;89:251-3.

69. Zaslau S, Nicolis C, Galea G, Britanico J, Vapnek JM. A simplified pharmacologic erection program for patients with spinal cord injury. J Spinal Cord Med 1999;22:303-7. 
Figure 1. Search strategy flowchart. ICI 1/4 intracavernous injection; PGE1 11/4 prostaglandin $E_{1} ; S$ CI 1/4 spinal cord injury

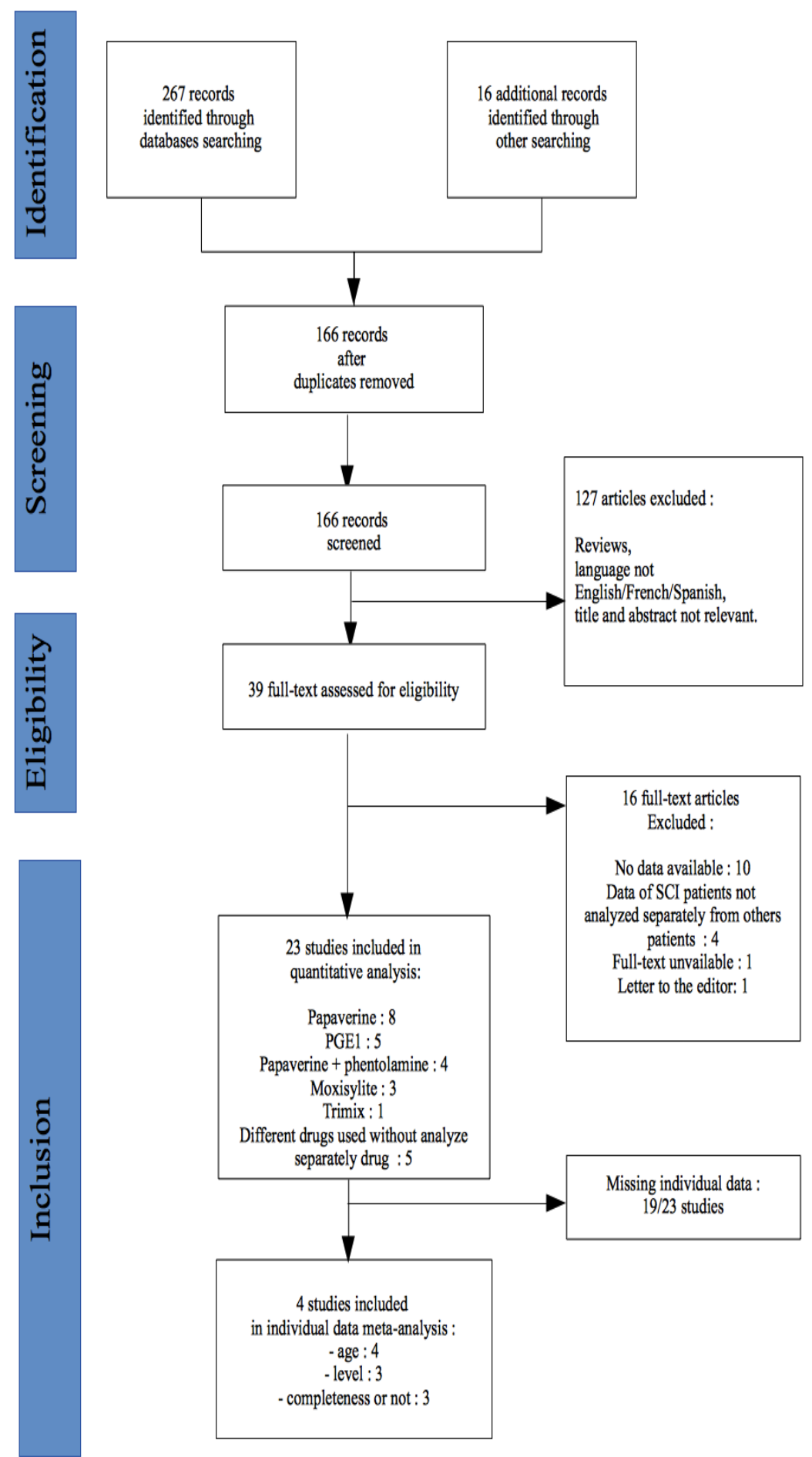


Figure 2. Meta-analysis of overall efficacy of intracavernous injection (all drugs).

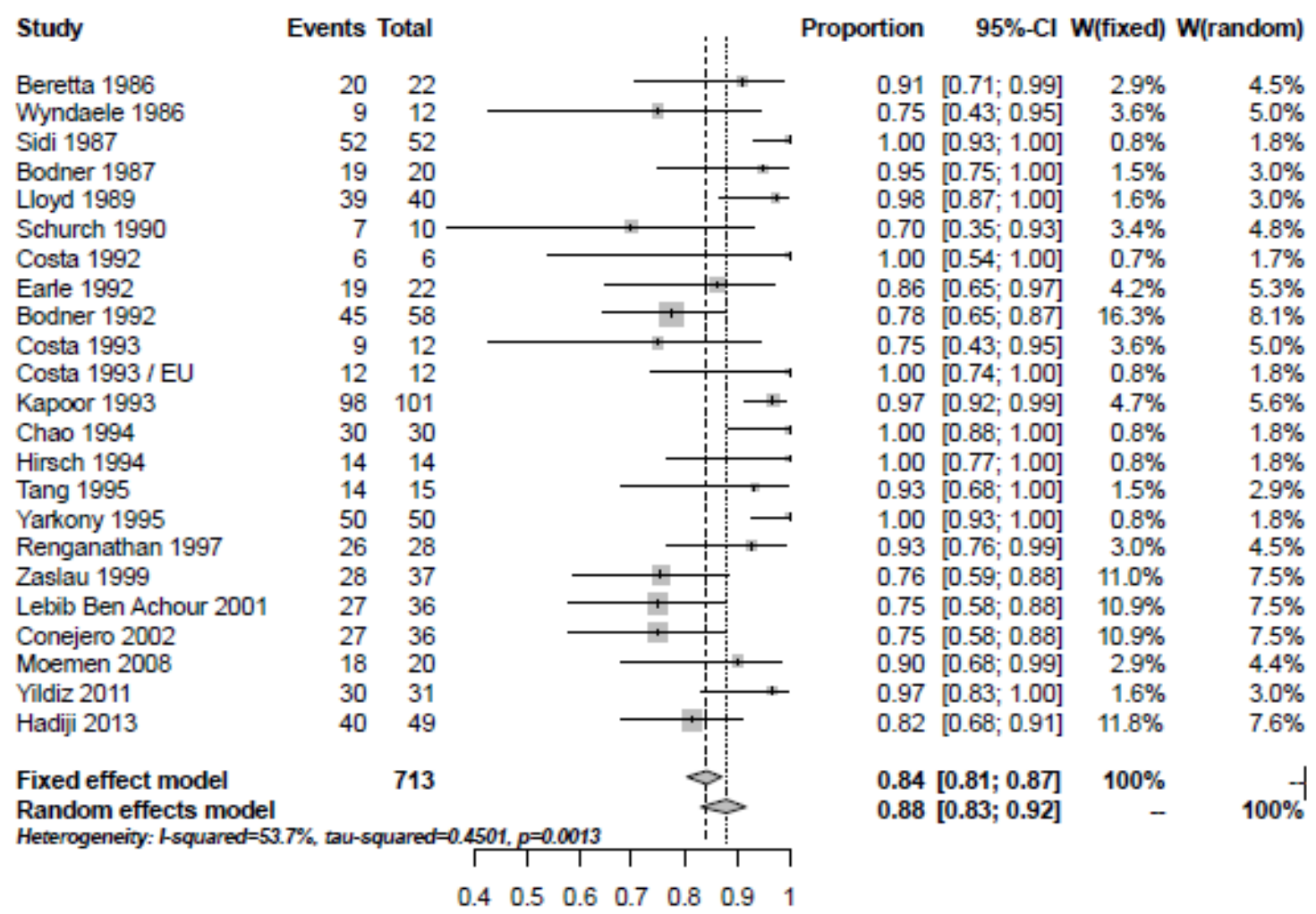



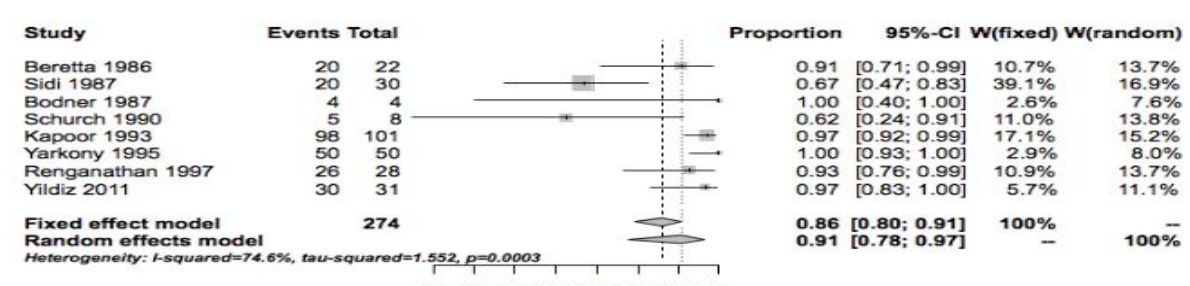

3.a) Meta-analysis of papaverine ICIs efficacy
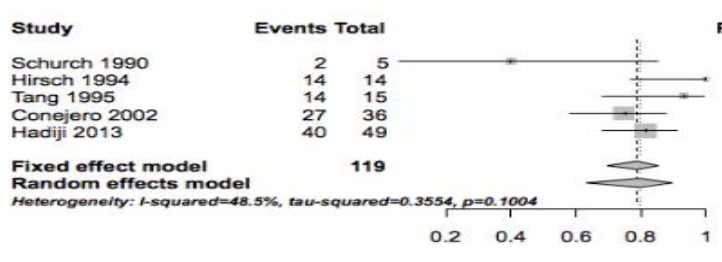

Proportion $95 \%-\mathrm{Cl} \mathbf{W}$ (fixed) W(random)

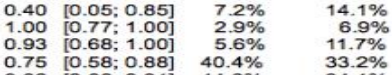

$\begin{array}{lll}0.79 & {[0.70 ; 0.86]} & 100 \% \\ 0.80 & {[0.64 ; 0.90]} & 0\end{array}$

$100 \%$

3.b) Meta-analysis of PGE1 ICIs efficacy

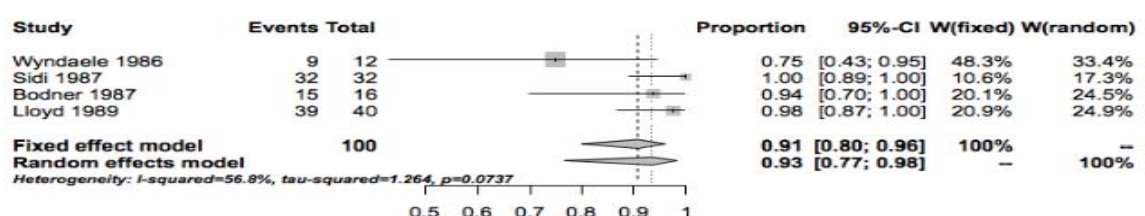

3.c) Meta-analysis of papaverine + phentolamine efficacy

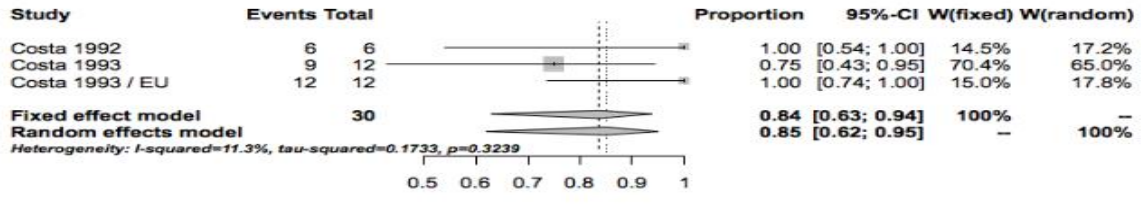

3.d) Meta-analysis of moxisylite efficacy

Figure 3: Meta-analysis per drug intracavernosally delivered: 3.a) Papaverine; 3.b) PGE1; 3.c) Papaverine + phentolamine; 3.d) Moxisylite. 
Table 1: Characteristics of the included studies

\begin{tabular}{|c|c|c|c|c|c|c|c|c|c|}
\hline $\begin{array}{l}\text { First Author } \\
\text { (year) }\end{array}$ & Study design & Drug intracavernosally delivered & Dose & $\begin{array}{l}\text { Number of } \\
\text { treated } \\
\text { patients }\end{array}$ & $\begin{array}{l}\text { Percentage of } \\
\text { responders (\%) }\end{array}$ & $\begin{array}{l}\text { Number of } \\
\text { responders }\end{array}$ & $\begin{array}{l}\text { Age (mean), } \\
\text { [min-max] }\end{array}$ & $\begin{array}{l}\text { Assessment of the } \\
\text { erectile response }\end{array}$ & $\begin{array}{l}\text { Quality } \\
\text { score }\end{array}$ \\
\hline Beretta (1986) & retrospective case-series & papaverine & $20-30 \mathrm{mg}$ & 22 & 90,1 & 20 & unk [18-52] & $\begin{array}{l}\text { Full erection allowing } \\
\text { intromission }\end{array}$ & $5 / 18^{\mathrm{IHE}}$ \\
\hline $\begin{array}{l}\text { Wyndaele } \\
\text { (1986) }\end{array}$ & retrospective case-series & papaverine + phentolamine & $\begin{array}{l}10-80 \mathrm{mg} / 2-10 \mathrm{mg} \\
\text { (titration) }\end{array}$ & 12 & 75 & 9 & 27 [unk] & Full erection & $5 / 18^{\mathrm{IHE}}$ \\
\hline Bodner (1987) & NR clinical trial & papaverine + phentolamine & $\begin{array}{l}5-60 \mathrm{mg} / 0- \\
2 \mathrm{mg}(\text { titration })\end{array}$ & 20 & 95 & 19 & $33[22-50]$ & $\begin{array}{l}\text { Erection allowing } \\
\text { intromission }\end{array}$ & $10 / 18^{\mathrm{IHE}}$ \\
\hline Sidi (1987) & retrospective case-series & papaverine + phentolamine & $\begin{array}{l}9,25-12,09 \mathrm{mg} / 0,204- \\
0,307 \mathrm{mg} \text { (titration) }\end{array}$ & 52 & 100 & 52 & $35,8[18-61]$ & $\begin{array}{l}\text { Erection allowing } \\
\text { intromission }\end{array}$ & $10 / 18^{\mathrm{IHE}}$ \\
\hline Lloyd (1989) & retrospective case-series & papaverine + phentolamine & $15 \mathrm{mg} / 0,25 \mathrm{mg}$ & 40 & 100 & 40 & 34,7 [unk] & $\begin{array}{l}\text { Self assessment } \\
\text { questionnaire / 10: } \\
\text { Satisfactory erection }\end{array}$ & $10 / 18^{\mathrm{IHE}}$ \\
\hline Schurch (1990) & retrospective case-series & PGE1/ Papaverine & $\begin{array}{l}10-20 \mu \mathrm{g} / 8-30 \mathrm{mg} \\
\text { (papaverine : titration) }\end{array}$ & 10 & 77,6 & 7 & $38,7[21-51]$ & $\begin{array}{l}\text { Erection allowing } \\
\text { intromission }\end{array}$ & $9 / 18^{\mathrm{IHE}}$ \\
\hline Bodner (1992 & retrospective case-series & papaverine $+/$ - phentolamine & $\begin{array}{l}5-60 \mathrm{mg} / 0,5-2 \mathrm{mg} \\
\text { (titration) }\end{array}$ & 58 & 77,6 & 45 & 37,7 [19-68] & $\begin{array}{l}\text { Erection allowing } \\
\text { intromission }\end{array}$ & $10 / 18^{\mathrm{IHE}}$ \\
\hline Earle (1992) & retrospective case-series & papaverine/papaverine+phentolamine/PGE1 & $\begin{array}{l}2-80 \mathrm{mg} / 0,5 \mathrm{mg} / \\
1-20 \mu \mathrm{g} \text { (titration) }\end{array}$ & 22 & 86,4 & 19 & 35,2 [20-45] & Full erection & $8 / 18^{\mathrm{IHE}}$ \\
\hline Costa (1992) & NR clinical trial & moxisylyte & $30 \mathrm{mg}$ & 6 & 100 & 6 & 31,2 [24-39] & Full erection & $10 / 22^{\text {STR }}$ \\
\hline $\begin{array}{l}\text { Costa } \\
\text { (1993/EU) }\end{array}$ & $\begin{array}{l}\text { double blind randomized } \\
\text { controlled clinical trial }\end{array}$ & moxisylyte & $\begin{array}{l}10-20-30 \mathrm{mg} \text { (cross- } \\
\text { over) }\end{array}$ & 12 & 75 & 9 & $35[20-50]$ & $\begin{array}{l}\text { Erection allowing } \\
\text { intromission (scale /3) }\end{array}$ & $16 / 22^{\mathrm{STR}}$ \\
\hline Costa (1993) & NR Clinical trial & moxisylyte & $20 \mathrm{mg}$ & 12 & 100 & 12 & $34[25-43]$ & $\begin{array}{l}\text { Erection allowing } \\
\text { intromission (scale /3) }\end{array}$ & $11 / 22^{\mathrm{STR}}$ \\
\hline
\end{tabular}




\begin{tabular}{|c|c|c|c|c|c|c|c|c|c|}
\hline $\begin{array}{l}\text { First Author } \\
\text { (year) }\end{array}$ & Study design & Drug intracavernosally delivered & Dose & $\begin{array}{l}\text { Number of } \\
\text { treated } \\
\text { patients }\end{array}$ & $\begin{array}{l}\text { Percentage of } \\
\text { responders }(\%)\end{array}$ & $\begin{array}{l}\text { Number of } \\
\text { responders }\end{array}$ & $\begin{array}{l}\text { Age (mean), } \\
\text { [min-max] }\end{array}$ & $\begin{array}{l}\text { Assessment of the } \\
\text { erectile response }\end{array}$ & $\begin{array}{l}\text { Quality } \\
\text { score }\end{array}$ \\
\hline Kapoor (1993) & retrospective case-series & papaverine & $7,5-60 \mathrm{mg}$ (titration) & 101 & 97 & 98 & unk [20-51] & $\begin{array}{l}\text { Erection allowing } \\
\text { intromission }\end{array}$ & $8 / 18^{\mathrm{IHE}}$ \\
\hline Chao (1994) & retrospective case-series & trimix 1 & $\begin{array}{l}1,5 \mu \mathrm{g} / 4 \mathrm{mg} / 0,02 \mathrm{mg} / \\
\text { (average, titration) }\end{array}$ & 30 & 100 & 30 & 36,3 [22-59] & $\begin{array}{l}\text { Erection allowing } \\
\text { intromission }\end{array}$ & $8 / 18^{\mathrm{IHE}}$ \\
\hline Hirsch (1994) & retrospective case-series & PGE1 & $\begin{array}{l}6,2 \mu \mathrm{g} \text { (average, } \\
\text { titration) }\end{array}$ & 14 & 100 & 14 & $31,5[22-39]$ & $\begin{array}{l}\text { Self assessment } \\
\text { questionnaire : } \\
\text { Satisfactory erection }\end{array}$ & $9 / 18^{\mathrm{IHE}}$ \\
\hline Tang (1995) & retrospective case-series & PGE1 & $15-20 \mu \mathrm{g}$ (titration) & 15 & 100 & 15 & $38,5[25-50]$ & Schrameck scale & $12 / 18^{\mathrm{IHE}}$ \\
\hline $\begin{array}{l}\text { Yarkony } \\
\text { (1995) }\end{array}$ & retrospective case-series & papaverine & 3 - $90 \mathrm{mg}$ (titration) & 50 & 100 & 50 & unk & Full erection & $7 / 18^{\mathrm{IHE}}$ \\
\hline $\begin{array}{l}\text { Renganthan } \\
\text { (1997) }\end{array}$ & $\begin{array}{l}\text { open randomized cross } \\
\text { over clinical trial }\end{array}$ & papaverine & $10-60 \mathrm{mg}$ (titration) & 28 & 92,9 & 26 & unk & Full erection & $16 / 22^{\text {STR }}$ \\
\hline Zaslau (1999) & retrospective case-series & PGE1 + papaverine & $\begin{array}{l}5-10 \mu \mathrm{g} / 15-30 \mathrm{mg} \\
\text { (titration) }\end{array}$ & 37 & 75,7 & 28 & $43,7[24-72]$ & Schrameck scale & $11 / 18^{\mathrm{IHE}}$ \\
\hline $\begin{array}{l}\text { Lebib Ben } \\
\text { Achour (2001) }\end{array}$ & prospective case-series & papaverine/ PGE1/ moxisylyte & $\begin{array}{l}20 \mathrm{mg} / 5-20 \mu \mathrm{g} / 10-20 \\
\mathrm{mg} / \mathrm{ml}\end{array}$ & 36 & 75 & 27 & $31[18-54]$ & Schrameck scale & $8 / 18^{\mathrm{IHE}}$ \\
\hline $\begin{array}{l}\text { Conejero } \\
(2002)\end{array}$ & NR clinical trial & PGE1 & $2-20 \mu \mathrm{g}$ (titration) & 36 & 75 & 27 & 38,5 [22-55] & $\begin{array}{l}\text { Erection allowing } \\
\text { intromission }\end{array}$ & $7,5 / 22^{\mathrm{STR}}$ \\
\hline $\begin{array}{l}\text { Moemen } \\
\text { (2008) }\end{array}$ & $\begin{array}{l}\text { cross over randomized } \\
\text { clinical trial }\end{array}$ & PGE1/trimix1 & unk & 20 & 90 & 18 & 32,7 [24-52] & $\begin{array}{l}\text { Erection allowing } \\
\text { intromission }\end{array}$ & $15 / 22^{\mathrm{STR}}$ \\
\hline Yildiz (2011) & $\begin{array}{l}\text { cross over randomized } \\
\text { clinical trial }\end{array}$ & papaverine & $25 \mathrm{mg}$ & 31 & 96,8 & 30 & 30,7 [19-46] & Scale $/ 4$ : Full erection & $16 / 22^{\mathrm{STR}}$ \\
\hline Hadiji (2013) & retrospective case series & PGE1 & $10-40 \mu \mathrm{g}$ (titration) & 49 & 81,6 & 40 & 37 [17-66] & Schrameck scale & $12 / 18^{\mathrm{IHE}}$ \\
\hline
\end{tabular}

1trimix=PGE1+papaverine+phentolamine

NR: non randomized unk: unknown

IIEF-EF : International Index of Erectile Function: Erectile Function domain score 
Table 2: Distribution of the injected drugs

\begin{tabular}{|c|c|c|c|c|}
\hline Drug & Number of patients & $\begin{array}{c}\text { Minimal } \\
\text { injected dose }\end{array}$ & $\begin{array}{c}\text { Maximal } \\
\text { injected dose }\end{array}$ & $\begin{array}{c}\text { Average dose } \\
\text { (calculated on } \mathrm{n} \\
\text { patients) }\end{array}$ \\
\hline papaverine & 274 & $2 \mathrm{mg}$ & $90 \mathrm{mg}$ & $16.6 \mathrm{mg}(\mathrm{n}=151)$ \\
\hline PGE 1 & 119 & $1 \mu \mathrm{g}$ & $40 \mu \mathrm{g}$ & $11.7 \mu \mathrm{g}(\mathrm{n}=34)$ \\
\hline $\begin{array}{c}\text { Papaverine + } \\
\text { phentolamine }\end{array}$ & 100 & $10 \mathrm{mg}+0.25 \mathrm{mg}$ & $80 \mathrm{mg}+10 \mathrm{mg}$ & $\begin{array}{c}14.9 \mathrm{mg} \text { and } 0,4 \mathrm{mg} \\
(\mathrm{n}=88)\end{array}$ \\
\hline moxisylyte & 30 & $10 \mathrm{mg}$ & $30 \mathrm{mg}$ & $22 \mathrm{mg}(\mathrm{n}=30)$ \\
\hline $\begin{array}{c}\text { trimix (papaverine+ } \\
\text { phentolamine + PGE 1) }\end{array}$ & 50 & $1 \mathrm{mg} / 0.01 \mathrm{mg} / 0,4 \mu \mathrm{g}$ & $13 \mathrm{mg} / 0.05 \mathrm{mg} / 5 \mu \mathrm{gg}$ & $\begin{array}{c}4 \mathrm{mg} / 0.02 \mathrm{mg} / 1.5 \mu \mathrm{g} \\
(\mathrm{n}=50)\end{array}$ \\
\hline
\end{tabular}

